\title{
As interpretações teológicas da Declaração Universal dos Direitos Humanos nas Mensagens comemorativas dos Pontificados Pós-conciliares (1968 a 2018)
}

\author{
Theological interpretations of the Universal Declaration \\ of Human Rights in the Post-Conciliar Papacy's \\ Commemorative Messages (1968 to 2018)
}

\section{Alex Villas Boas, Aline Vicentim Villas Boas*}

Pontifícia Universidade Católica do Paraná (PUCPR), Curitiba, PR, Brasil

\section{Resumo}

0 presente artigo tem o objetivo de analisar as ênfases hermenêuticas e teológicas que os papados pós-conciliares, de 1968 a 2018, deram em suas Mensagens comemorativas da Declaração Universal dos Direitos Humanos, respectivamente às datas dos $20^{\circ}, 25^{\circ}, 30^{\circ}, 40^{\circ}, 50^{\circ}, 60^{\circ}$ e $70^{\circ}$ aniversários. Para isso, irá se analisar como a gramática dos Direitos Humanos é incorporada no Magistério Católico, com João XXIII, e consolidada no Concílio Vaticano Il que gera duas grandes ênfases hermenêuticas da dignidade humana, da liberdade humana e das condições de vida digna por meio da

*AVB: Doutor em Teologia, e-mail: alex.boas@pucpr.br

AVVB: Mestre em Direitos Humanos, e-mail: alinevvillasboas@gmail.com 
justiça social. Os papados pós-conciliares irão desenvolver tais dimensões de acordo com suas respectivas perspectivas e contextos.

Palavras-chaves: Declaração Universal dos Direitos Humanos. Pontificados pós-conciliares. Liberdade. Justiça Social. Teologia e Direitos Humanos

\section{Abstract}

This article aims to investigate the post-Conciliar Papacy hermeneutical and theological emphases expressed in their respective Universal Declaration of Human Rights commemorative messages, from 1968 to 2018, celebrating the dates of 20th, 25th, 30th, 40th, 50th, 60th and 70th anniversaries of the international document. In order to accomplish such goals, this research analyzes how the human rights grammar is incorporated into the Catholic Magisterium, initiated with John XXIII and consolidated in the Second Vatican Council. The text raises two major emphasis on human dignity hermeneutics, liberty and conditions of dignified life through social justice. The post-Conciliar papacy will develop such dimensions in accordance with their respective perspectives and contexts.

Keywords: Human Rights Universal Declaration. Post-Conciliar pontificates. Liberty. Social Justice. Theology and Human Rights.

\section{Introdução}

A análise das práticas discursivas da Igreja Católica em relação aos Direitos Humanos sofre uma evolução histórica. Há uma primeira fase refratária, que diz respeito ao vínculo entre o Estado Liberal, o humanismo moderno e valorização da capacidade de autonomia do ser humano e os "novos direitos", como eram nomeados pela teologia magisterial católica. Tais direitos colocavam em xeque o poder temporal da Cristandade e eram vistos como uma "ideologia" que rompia com os "princípios católicos", como reminiscência do espírito iluminista e as repercussões políticas da 
Revolução Francesa, de onde surgem os Direitos universais do Homem e do Cidadão, em 1789. Esta perspectiva se estende até o século XX, não havendo referência a tais direitos nem mesmo na Encíclica social Rerum Novarum de Leão XIII, escrita em 1891 (CALDEIRA, 2017, p. 777).

Na primeira metade do século XX, contudo, o anseio pela paz e o apelo a uma convivência social marcada pela justiça, liberdade e promoção do bem mútuo e pela independência das nações seriam considerados sinais do Reino de Deus. Portanto, abririam espaço para o reconhecimento da gramática da dignidade humana presente na Declaração Universal dos Direitos Humanos (DUDH), aprovada e proclamada pela Assembleia Geral das Nações Unidas (ONU), em Paris no dia 10 de dezembro de 1948, por meio da Resolução 217 A (III) da Assembleia Geral ${ }^{1}$ como uma norma comum a ser alcançada por todos os povos e nações:

todo ser humano tem direito à liberdade de pensamento, consciência e religião; este direito inclui a liberdade de mudar de religião ou crença e a liberdade de manifestar essa religião ou crença, pelo ensino, pela prática, pelo culto e pela observância, em público ou em particular (ONU, 1948, art. 18).

A incorporação da gramática dos Direitos Humanos é uma das características inegáveis do Catolicismo contemporâneo, que, desde João XXIII e consolidada no Concílio Vaticano II, permanece uma constante nos pontificados pós-conciliares. Cabem à análise da hermenêutica teológica as ênfases que cada pontífice dá aos Direitos Humanos. A proposta do presente artigo é analisar as ênfases que a Teologia Magisterial dos últimos pontífices pós-conciliares dá à Declaração Universal dos Direitos Humanos. Considerar-se-á a incorporação de suas premissas nos documentos pontifícios nas Encíclicas Mater et Magistra e Pacem in terris de João XXIII, nas apropriações e hermenêuticas teológicas que o Concílio Vaticano II faz da gramática dos Direitos Humanos, para em um segundo momento analisar as Mensagens pontifícias referentes à celebração dos aniversários da proclamação da Declaração Universal dos Direitos Humanos, que desde

1 Disponível em <http://www.un.org/ga/search/view_doc.asp?symbol=A/RES/217(III)\&Lang=E>. Acesso em 10 fev. 2019. 
1950 é comemorada todo dia de 10 de dezembro. Serão consideradas as seguintes mensagens pontifícias celebrativas da DUDH:

Tabela 1 - Mensagens Pontifícias pelo Aniversário da DUDH

\begin{tabular}{|c|c|c|}
\hline \multirow{2}{*}{1968} & \multirow{2}{*}{ Paulo VI } & XX Aniversário \\
\cline { 1 - 1 } 1973 & \multirow{2}{*}{ João Paulo II } & XXV Aniversário \\
\cline { 1 - 1 } 1978 & & XXX Aniversário \\
\cline { 1 - 1 } 1988 & Bento XVI & XL Aniversário \\
\hline 1998 & Francisco & LX Aniversário \\
\hline 2008 & LX Aniversário \\
\hline 2018 & LXX Aniversário \\
\hline
\end{tabular}

Fonte: Sítio eletrônico oficial do Vaticano ${ }^{2}$.

\section{Os Direitos Humanos em João XXIII (1881-1963)}

João XXIII será o primeiro pontífice a fazer tal reconhecimento. Já em 1961, em sua Encíclica Mater et Magistra [=MM], fala da "razão de ser" do "Estado" que é a "realização do bem comum" e, ainda, "proteger os direitos de todos os cidadãos, sobretudo dos mais fracos, como são os operários, as mulheres e as crianças" contribuindo "ativamente para melhorar as condições de vida dos operários” (MM 20). Há em João XXIII uma clara correlação entre a "presença do Estado no campo econômico" e sua tarefa de garantir os "direitos essenciais da pessoa humana" (MM 55) promovendo uma socialização responsável como "obra de seres conscientes e livres" que

torna possível satisfazer muitos direitos da pessoa humana, especialmente os chamados econômicos e sociais, por exemplo, o direito aos meios indispensáveis ao sustento, ao tratamento médico, a uma educação de base mais elevada, a uma formação profissional mais adequada, à

2 Cf. Disponivel em: <http://w2.vatican.va/content/john-xxiii/pt/encyclicals/documents/hf_j-xxiii_ enc_15051961_mater.html>. Acesso em: 10 fev. 2019. 
habitação, ao trabalho, a um repouso conveniente e à recreação (MM, 61-63, grifo nosso).

João XXIII chega a relacionar a questão dos "direitos elementares da pessoa humana" ao problema da desigualdade social e do desenvolvimento econômico e os trata como o principal problema da época moderna:

O maior problema da época moderna talvez seja o das relações entre as comunidades políticas economicamente desenvolvidas e as que se encontram em vias de desenvolvimento econômico; as primeiras, por conseguinte, com alto nível de vida, as outras, em condições de escassez ou de miséria. A solidariedade, que une todos os seres humanos e os torna membros de uma só família, impõe aos países, que dispõem com exuberância de meios de subsistência, o dever de não permanecerem indiferentes diante das comunidades políticas cujos membros lutam contra as dificuldades da indigência, da miséria e da fome, e não gozam dos direitos elementares da pessoa humana. Tanto mais que, dada a interdependência cada vez maior entre os povos, não é possível que entre eles reine uma paz durável e fecunda, se o desnível das condições econômicas e sociais for excessivo (MM 156).

Em 1963, em sua Encíclica Pacem in terris [=PT], o Papa Buono consagra a expressão "direitos do homem", entendendo que "universalmente" prevalece a "opinião de que todos os seres humanos são iguais entre si por dignidade de natureza" (PT 44), e reconhece como um "ato de altíssima relevância" a "Declaração Universal dos Direitos do Homem” escrita pelas Nações Unidas (PT 142). Ademais, a Declaração, como expressão da consciência de superação das "opiniões que admitiam classes inferiores de homens e classes superiores, derivadas de situação econômico-social, sexo ou posição política" é um sinal da presença do Reino e uma via espiritual, uma

estrada a conhecer melhor o verdadeiro Deus transcendente e pessoal e a colocar então as relações entre eles e Deus como fundamento de sua vida: da vida que vivem no próprio íntimo e da vida em relação com os outros homens (PT 43) 
Entretanto, tal via espiritual está visceralmente ligada às relações humanas na tarefa de garantir um "digno padrão de vida" condizente com tal dignidade:

E, ao nos dispormos a tratar dos direitos do homem, advertimos, de início, que o ser humano tem direito à existência, à integridade física, aos recursos correspondentes a um digno padrão de vida: tais são especialmente o alimento, o vestuário, a moradia, o repouso, a assistência sanitária, os serviços sociais indispensáveis. Segue-se daí que a pessoa tem também o direito de ser amparada em caso de doença, de invalidez, de viuvez, de velhice, de desemprego forçado, e em qualquer outro caso de privação dos meios de sustento por circunstâncias independentes de sua vontade (PT 11).

Para João XXIII o "bem comum" consiste de modo especial no "respeito aos direitos e deveres da pessoa humana" devendo os poderes públicos se empenhar para que tais direitos sejam "reconhecidos, respeitados, harmonizados, tutelados e promovidos", pois "a função primordial de qualquer poder público é defender os direitos invioláveis da pessoa e tornar mais viável o cumprimento dos seus deveres" (PT 60).

\section{Os Direitos Humanos no Concílio Vaticano II (1962-1965)}

O Concílio Vaticano II nasce imbuído desse clima cultural e teológico legitimado e impulsionado por João XXIII. Apesar de o Concílio não citar explicitamente a DUDH, ela assume sua semântica e, principalmente, os debates decorrentes da interpretação da mesma naquele momento, assumindo o consensus omnium gentium que consolidava um sistema de valores em torno da dignidade humana comum (BOBBIO, 2004, p. 18). A temática dos Direitos Humanos aparece com os termos principais na Gaudium et Spes [=GS] e na Dignitatis humanae [=DH] como hominis iura, personae humanae iura e iura hominum fundamentalia (DH 6; GS 
21; 29), porém é referenciada 24 vezes $^{3}$, como expressão concreta do serviço prestado à dignidade humana. Deste modo, o Concílio dedicará uma antropologia teológica da dignidade humana que se concentra na Declaração Dignitatis Humanae e apresentará a forma de operacionalizar uma teologia prática sobre os Direitos Humanos na Constituição Pastoral Gaudium et Spes.

A ideia da Gaudium et Spes surge no Concílio ao final da sua I Seção, por conta de um discurso do Cardeal Suenens em 07 de dezembro de 1962, resultando na criação de uma comissão mista, constituída pela Comissão Teológica e a Comissão para o Apostolado dos Leigos, que elaborou um primeiro esquema chamado De presentia Ecclesiae in mundo hodierno. Esta ideia, porém, foi debatida ao longo de todo o Concílio e foi aprovada somente na Sessão Pública de 07 de dezembro de 1965. A Declaração Dignitatis humanae sobre a Liberdade Religiosa inicialmente foi apresentada como Capítulo V do primeiro esquema do Decreto sobre o Ecumenismo apresentado pelo Secretariado para a União dos Cristãos na Segunda Sessão, em novembro de 1963. Na III Seção do Concílio, em 1964, já aparece com uma nova redação, separada do Decreto sobre o Ecumenismo na forma de Declaração, porém só aprovada em sua sexta redação na mesma Seção Pública em que fora aprovada a Gaudium et Spes (CONCÍLIO VATICANO II, 2000, p. 142; 598), de modo que as discussões sobre a Dignidade Humana e os Direitos Humanos percorrem todo o Concílio Vaticano II.

A antropologia teológica da dignidade humana começa com uma influência joanina de reconhecer essa "evolução" de mentalidade, essa crescente consciência da dignidade da pessoa humana como um sinal da ação do "Espírito de Deus que dirige o curso dos tempos e renova a face da terra com admirável providência" suscitando o "fermento evangélico" que "despertou e desperta no coração humano uma irreprimível exigência de dignidade" (GS 26, 2-4). Ademais, a "razão mais sublime da dignidade humana consiste na sua vocação à união com Deus”, pois tal dignidade é criada e conservada por Deus "por amor", sendo o caminho de diálogo

3 Cf. Gaudium et Spes nn. 4; 21,6; 26,2; 27,1-3; 29,1-4; 73,1-5; 75, 1-3; 91,1. Cf. Dignitatis Humanae nn. 1-15; Inter mirifica n. 5,2; Gravissium Eduationis n. 1. 
e união com Deus um caminho de desvelamento do sentido profundo da dignidade humana. A religião deveria assim ser este espaço de desvelamento da consciência humana, mas não raro é também responsável por favorecer o ateísmo quando se desvia de sua responsabilidade com as relações humanas. A "gênese do ateísmo", segundo o texto, não raro é fruto de um protesto violento do mal do mundo somado às formas religiosas que visam justificá-lo, pela "negligência" na educação da fé, por "exposições falaciosas da doutrina", pelas "deficiências" da "vida religiosa, moral e social" que "antes esconderam do que revelaram o autêntico rosto de Deus e da religião" (GS 19). A crescente consciência [magis] da dignidade humana "[reivindica] a capacidade de agir segundo a própria convicção e com liberdade responsável”, o que exige romper com qualquer forma de coação na conduta das consciências (DH 1). Da própria condição da dignidade humana brota a consciência da liberdade religiosa, que segundo o Concílio tem raízes na própria Revelação cristã, oriunda do "respeito de Cristo pela liberdade do ser humano" (DH 9).

Entretanto, além da ênfase na liberdade com expressão da dignidade humana que se desdobra na liberdade religiosa, o Concílio estabelece um vínculo indissociável de sua antropologia teológica entre a verdade e o amor, sendo sua expressão política e social a justiça [veritatem facientes in caritate] (VILLAS BOAS, 2015, p. 1003-1006). Deste modo, há pelo menos duas ênfases na hermenêutica teológica conciliar dos Direitos Humanos: a da liberdade, que inclui a liberdade religiosa; e a construção da justiça, pois a dignidade humana implica ser "fundada na verdade, construída sobre a justiça e vivificada pelo amor", como elementos que podem promover um equilíbrio no ritmo das mudanças que exigem "renovação da mentalidade" [mentis renovatio] e "introdução de amplas reformas sociais" [amplae societatis immutationes] (GS 26,3). Deste modo, se a verdade da dignidade humana diz respeito à tarefa da mentis renovatio, compete à consciência cristã da indissociabilidade entre amor e justiça garantir a defesa e promoção dos Direitos Humanos, por meio da implementação das reformas que assegurem o acesso a todas as coisas que possibilitem uma vida "verdadeiramente humana", considerando o próximo como um "outro eu”, a saber: 
alimento, vestuário, casa, direito de escolher livremente o estado de vida e de constituir família, direito à educação, ao trabalho, à boa fama, ao respeito, à conveniente informação, direito de agir segundo as normas da própria consciência, direito à proteção da sua vida e à justa liberdade mesmo em matéria religiosa (GS 26,2; 27).

Nesse sentido a hermenêutica teológica da Gaudium et Spes é de denúncia das contradições do tempo hodierno marcadas pelas tensões entre, por um lado, "grande abundância de riquezas" e, por outro, uma "imensa parte dos habitantes da terra" atormentados pela "fome", "miséria" e "inúmeros analfabetos"; entre um "tão vivo sentido da liberdade" contemporânea e as "novas formas de servidão social e psicológica"; entre a experiência de "unidade", "interdependência mútua" e sentimento de "solidariedade" e a as "forças antagónicas" dos "agudos conflitos políticos, sociais, económicos, 'raciais' e ideológicos" que sempre despertam o risco de guerra "que tudo subverta". Ademais, se por um lado "aumenta o intercâmbio das ideias”, há, por sua vez, uma indisposição ao diálogo em que as "próprias palavras com que se exprimem conceitos da maior importância" acabam por assumir "sentidos muito diferentes segundo as diversas ideologias". Dada a complexidade do mundo contemporâneo, se impõe a tarefa de "discernir os valores verdadeiramente permanentes e de os harmonizar com os novamente descobertos" acerca da "evolução atual dos acontecimentos" (GS 4,3-4) para que se clarifiquem as consciências de que "todos os homens, crentes e não-crentes devem contribuir para a reta construção do mundo no qual vivem em comum" (GS 21,6).

Todas as formas de defesa dos Direitos Humanos de "tudo quanto se opõe à vida" e "tudo quanto ofende a dignidade da pessoa humana" atentam contra a "imagem de Deus", e é "contrária à vontade de Deus, qualquer forma social ou cultural de discriminação, quanto aos direitos fundamentais da pessoa, por razão do sexo, raça, cor, condição social, língua ou religião" (GS 29, 1-2). Explicita-se, ainda a tarefa da comunidade política de se empenhar em "assegurar o direito das minorias" (GS 73, 3). Conclui o Concílio, assumindo seu compromisso em fomentar uma cultura de Direitos Humanos que 
pretende ajudar todos os homens do nosso tempo, quer acreditem em Deus, quer não $\mathrm{O}$ conheçam explicitamente, a que, conhecendo mais claramente a sua vocação integral, tornem o mundo mais conforme à sublime dignidade do homem, aspirem a uma fraternidade universal mais profundamente fundada e, impelidos pelo amor, correspondam com um esforço generoso e comum às urgentes exigências da nossa era (GS 91,1).

O Concílio procede assim, no que diz respeito a sua posição relativa à gramática dos Direitos Humanos, em quatro direções, reafirmando seus fundamentos com uma interpretação teológica dos mesmos, e a sua universalização que se desdobra na especificação de vários direitos que devem ser considerados humanos, para consequentemente incentivar a proteção e realização dos mesmos (QUEIROZ, 2015, p. 288-292). No que diz respeito às demandas pós-conciliares, implica as tarefas de uma educação em Direitos Humanos a fim de promover uma renovação da mentalidade e a implementação das reformas sociais. E por fim, no que se refere às ênfases teológicas da dignidade humana, acentua a hermenêutica da liberdade (DH 1-15) e a hermenêutica da justiça social (GS 29,3) como exigências da paz na contemporaneidade.

\section{Mensagens Pontifícias pelo aniversário da DUDH}

As Mensagens Pontifícias pelo aniversário da DUDH são documentos sintéticos que permitem evidenciar as principais ênfases das hermenêuticas teológicas magisteriais dos Direitos Humanos, constituindo assim uma documentação que permite uma visão panorâmica e ao mesmo tempo programática da questão em cada pontificado.

\section{Mensagens Pontifícias de Paulo VI pelo aniversário da DUDH}

Paulo VI (1963-1978) é o herdeiro espiritual de João XXIII, que no leito de morte confere ao então Cardeal Giovanni Montini (1897-1978) uma missão: "Confio-lhe a igreja, o concílio, a paz" (GONÇALVES, 2015, p. 729). Compreende que as últimas páginas do concílio, a Gaudium et 
Spes se constituem como o "encontro da Igreja como mundo atual" e devolvem o lugar da igreja no "meio da vida contemporânea", porém não para julgar a sociedade, mas para "iluminá-la, sustentá-la e consolá-la". A Gaudium et Spes é o "ponto de encontro entre Cristo e o homem moderno" (PAULO VI, 1965) e o pontífice que conclui o Concílio adota o princípio magis magisque, de cada vez mais adaptar a igreja aos "novos fins" e "áreas de apostolado" abertos para "atender as necessidades modernas" (PAULO VI, 1966). Tendo por base a GS 90,3, que evoca a criação de um organismo da igreja católica universal que seja "incumbido de estimular a comunidade católica na promoção do progresso das regiões necessitadas e da justiça social entre as nações", cria a Pontifícia Comissão Justitia et Pax em 1967 (PAULO VI, 1967b).

Em 15 de abril de 1968, Paulo VI é o primeiro pontífice da igreja católica a publicar uma Mensagem referente ao $20^{\circ}$ Aniversário da Declaração Universal dos Direitos Humanos. Na análise histórica da DUDH, contra as "objeções" e "justificadas reservas" da declaração, faz menção às palavras de João XXIII de que a mesma "marcou um passo importante para o estabelecimento de uma organização jurídico-política da Comunidade mundial" e para promover uma nova consciência histórica em que afirma a dignidade de todos os seres humanos, bem como o direito de cada um de "buscar livremente a verdade, de seguir as normas da moral, de praticar os deveres da justiça, de exigir condições de vida conforme à dignidade humana".

$\mathrm{Na}$ análise teológica, recorda que, durante o Concílio Vaticano, evoca a Pacem in terris de João XXIII como "verdadeiro testamento espiritual" que reconhece a DUDH como "sinais dos tempos" e "bem comum da humanidade". O fundamento dos Direitos Humanos deriva "diretamente da dignidade natural" e exorta todos os seres humanos a viverem como “irmãos", porque "todos são filhos do Deus vivo", evocando sua Encíclica Populorum Progressio (nn. 2, 6, 13 e 21). Deste modo, o programa das Nações Unidas é também o programa da igreja, de modo que "todo tipo de discriminação dos direitos fundamentais da pessoa humana" é "contrário ao desígnio de Deus”. Chama, assim, o povo de Deus para cooperação, "não só ao proclamar os princípios da Declaração, mas colocá-los em prática, aos Estados não só promulgarem-na em suas constituições, mas 
aplicá-las, para que todos os homens possam finalmente viver uma vida digna" e trabalhar na construção de uma comunidade fraterna ao agir por um mundo em que "cada um é amado e ajudado como seu vizinho e seu irmão". A "regra suprema" que sustenta teologicamente a DUDH é evocada das Bem-aventuranças do Evangelho: "Tudo aquilo, portanto, que quereis que os homens vos façam, fazei-o vós a eles” (Mt 7,12).

A respeito dos principais desafios, alerta que seria inútil "proclamar direitos, se ao mesmo tempo não se implementar tudo o necessário para garantir o dever de respeitá-los, para todos, em todos os lugares e para todos". Indica o desafio de "traduzir os princípios em atos" para a eliminação das numerosas e constantes violações de princípios proclamados como universais, invioláveis e inalienáveis. Entre as principais violações denunciadas enfatiza a necessidade de medidas para enfrentar a "discriminação racial", fonte de "perturbações e injustiça social", a "miséria econômica" e a "opressão ideológica". Dá destaque ao direito à educação ["derrotar o analfabetismo"] e o direito à igualde de gênero ["dar à mulher seu legítimo lugar na sociedade"] (PAULO VI, 1968).

Em 10 de dezembro de 1973, Paulo VI, em sua análise histórica do $25^{\circ}$. Aniversário da DUDH, afirma que a declaração dos direitos humanos "ainda é para nós um dos mais belos títulos de glória", especialmente se a leva em conta como um caminho seguro para a paz. Diz ainda que "a paz e a lei são dois bens diretamente e reciprocamente relacionados como causa e efeito: não pode haver uma paz real onde os direitos humanos não sejam respeitados, defendidos e promovidos. Se esta promoção dos direitos da pessoa humana conduz à paz, a paz em sua parte favorece sua realização". Afirma também que o texto é "expressão de uma consciência mais madura e mais precisa dos direitos da pessoa humana".

Em sua análise teológica, diz que "os direitos humanos são fundados na dignidade reconhecida de todos os seres humanos, na sua igualdade e fraternidade", portanto, o dever de respeitar esses direitos tem caráter universal e é capaz de converter a "família humana" em uma "comunidade mundial de irmãos", em que todos os filhos dos homens podem "levar uma vida digna de filhos de Deus", "feitos a imagem e semelhança de seu Criador". Por isso a igreja se sente ferida quando "os direitos humanos, quaisquer que sejam, e onde quer que sejam, se 
ignora e os violam”. Deste modo, declara "adesão moral às atividades das Nações Unidas em favor da justiça, da paz e do desenvolvimento de todos os povos", impulsionado pela consciência missiológica "que consiste em fazer presente, vivo e atual a mensagem de salvação proclamada por Cristo". Ainda ao final da mensagem, volta a afirmar que "a Santa Sé empresta o seu pleno apoio moral ao ideal comum contido na declaração universal, bem como ao progressivo ensaio dos direitos humanos nele formulados" (PAULO VI, 1973).

Elenca como principais desafios que seria "lamentável para a humanidade que tal proclamação solene fosse reduzida a um reconhecimento vão de valores ou a um princípio doutrinal abstrato, que permaneceria sem aplicação concreta", pois "a promoção destes direitos é um fator de paz; seu abuso é a causa de tensões e convulsões, mesmo a nível internacional”. Assim, clama para a não indiferença na construção de "uma comunidade de vida humana que garanta o indivíduo, os grupos e, em particular, as minorias, o direito à vida, a dignidade pessoal e social, o desenvolvimento em um ambiente protegido e melhorado, bem como a distribuição equitativa das riquezas da natureza e os frutos da civilização" e critica as objeções dos Estados em proteger e promover os Direitos Humanos. Entre tais objeções menciona a compreensão de que a colaboração de todos os Estados para promover os direitos humanos constituiria uma ingestão nos assuntos internos dos países, porém contrapõe tal afirmação ao questionar se "a forma mais segura para o Estado evitar interferências é justamente reconhecer e garantir, nos territórios da sua jurisdição, o respeito pelos direitos e liberdades fundamentais?”. Faz-se necessário "analisar as causas profundas destas situações e comprometer-se decididamente a enfrentá-las e resolvê-las corretamente" (PAULO VI, 1973).

Entre as principais violações denunciadas, declara preocupação em situações de violação dos direitos "como a discriminação racial ou étnica, os obstáculos à autodeterminação dos povos, a repetição de violações do direito sagrado à liberdade religiosa em seus vários aspectos, a supressão da liberdade de expressar opiniões sólidas, o tratamento desumano dos prisioneiros, a eliminação violenta e sistemática de adversários políticos, as demais formas de violência e ataques à vida humana, 
particularmente no ventre materno". Por fim, entre os destaques, declara ser "animador ver a sensibilidade que os homens mostram em relação aos valores fundamentais contidos na declaração universal". Entende que a "multiplicação de reclamações e demandas" é um "sinal sintomático" da "crescente sensibilidade" à "multiplicação dos ataques" que atentam contra as "liberdades inalienáveis do homem e das coletividades" (PAULO VI, 1973).

\section{Mensagens Pontifícias de João Paulo II pelo aniversário da DUDH}

João Paulo II (1978-2005) é seguramente o papa que mais escreveu sobre os Direitos Humanos, não somente pelo seu longo pontificado de 26 anos, mas por ser também uma questão particularmente importante na trajetória e na vida de Karol Wojtyla (1920-2005).

Em 2 de dezembro de 1978, João Paulo II escreve sua primeira Mensagem por ocasião do $30^{\circ}$ Aniversário da Declaração dos Direitos Humanos, e em uma análise histórica, fala das declarações (Universal, a Convenção Internacional sobre os Direitos Econômicos, Sociais e Culturais e a Convenção Internacional sobre os Direitos Civis e Políticos) como instrumentos jurídicos destinados a tutelar ideais. Da mesma forma, felicita a organização das Nações Unidas por "estabelecer juridicamente instrumentos válidos de promoção dos direitos humanos das pessoas e de promover as suas liberdades fundamentais" e cita a adoção destes documentos como uma forma de "promover com garantias legais os direitos de todos os homens e mulheres, sem discriminação de raça, sexo, língua ou religião".

$\mathrm{Na}$ análise teológica da mensagem, afirma que os Direitos Humanos Fundamentais estão claramente expressos na "mensagem do Evangelho". O papa polonês aposta no papel dos crentes: "permitindo a Deus que fale ao homem é que mais verdadeiramente eles contribuem para reforçar a consciência, que todo o ser humano tem, do seu destino, e para se convencerem de que todos os direitos emanam da dignidade da pessoa, que está firmemente enraizada em Deus". A defesa dos Direitos Humanos, é por sua vez, "oferecida e conferida" como "missão própria" 
da Igreja, dando ênfase a defesa da liberdade como "característica proeminente da humanidade" e "fonte de que deriva a dignidade humana" como "o sinal excepcional da imagem divina impressa no homem”, evocando o Concílio (GS 17).

No que diz respeito aos principais desafios, denuncia uma "espécie de 'confessionalismo em negativo'”, em que haveria uma intolerância religiosa promovida por uma confissão de ateísmo. Assim, critica certos regimes: "embora a liberdade de culto religioso seja reconhecida na Constituição, no entanto os poderes públicos esforçam-se por afastar os cidadãos de professarem a religião e por tornar muito difícil e perigosa a vida às comunidades religiosas". Quanto às principais violações, faz referência específica sobre a contínua violação de direitos civis, dando ênfase ao "direito de nascer, o direito à vida, o direito à paternidade responsável, ao trabalho, à paz, à liberdade e à justiça social, e o direito de participar nas decisões que interessam os povos e as nações”. Menciona discriminação racial, torturas físicas e psicológicas e sequestros (derivadas de processos políticos). Sobre os destaques wojtylianos, após fazer referência à dignidade humana como base dos direitos humanos e da religião, faz menção específica aos princípios de liberdade de pensamento, de consciência e de religião ao pedir que "a liberdade religiosa de todas as pessoas e todos os povos fosse respeitada em toda a parte e por todos". Enfatiza que "o livre exercício da religião beneficia tanto os indivíduos como os governos. Portanto, a obrigação de respeitar a liberdade religiosa incumbe a todos, tanto cidadãos particulares como autoridades civis legítimas" (JOÃO PAULO II, 1978).

Em 10 de dezembro de 1988, escreve sua segunda Mensagem por ocasião do $40^{\circ}$ Aniversário da Declaração dos Direitos Humanos e fala, sem sua análise histórica da DUDH, do papel da Declaração em afirmar a "chegada de um mundo em que todos possam gozar de liberdade de falar e de crer" e expressar o "ideal comum a ser alcançado por todos os povos e nações, tomando as medidas progressivas na ordem nacional e internacional". Também fala do trabalho da ONU como mantenedora dos instrumentos jurídicos adequados para definir os princípios fundamentais da DUDH. Na sua análise teológica dos 40 anos da DUDH, menciona o dever da igreja de proporcionar igualdade a todos como 
filhos de Deus e reafirmar os "fundamentos transcendentes dos direitos humanos" e de "animar ações dinâmicas para promover esses direitos. Termina afirmando que, "de acordo com o ensinamento da igreja, os direitos do homem se fundam em Deus Criador, que dotou toda pessoa de inteligência e liberdade, e desejou que a organização da sociedade esteja a serviço do ser humano".

Apresenta com principais desafios que a "meta" da DUDH "ainda não foi alcançada", como se evidencia nos trabalhos das comissões "ad hoc", a fim de esclarecerem a "aplicação dos princípios, desenvolver instrumentos legais apropriados e examinar as violações dos direitos humanos". Clama, portanto, aos "poderes públicos" e à intervenção do "Estado" para obter a garantia dos direitos humanos, como condição para se alcançar "grau superior de civilização". Dita em principais violações denunciadas a indignação de que "ainda hoje centenas de milhões de seres humanos têm constantemente ameaçados seus direitos à vida, à liberdade, à segurança", à igualdade entre todos e à dignidade de todos como fala das "novas barreiras" ideológicas que desrespeitam a dignidade humana "por motivos de raça, cor, sexo, idioma, religião, opiniões políticas ou outros tipos de convicções, de origem nacional ou social". Em seus destaques faz referência a direitos individuais e coletivos ao questionar que algumas violações prejudicam os direitos tanto das pessoas como de grupos humanos. Dessa forma coloca como sujeito de direito grupos socialmente excluídos e vulneráveis (JOÃO PAULO II, 1988).

Em 30 de novembro de 1998, escreve sua terceira Mensagem por ocasião do $50^{\circ}$ Aniversário da Declaração dos Direitos Humanos e comporta em sua análise histórica, uma vez mais, o reconhecimento da DUDH como "um dos documentos mais preciosos e significativos da história do direito", afirmando ainda que o documento "contribuiu de maneira decisiva para o desenvolvimento do direito internacional, que interpelou legislações nacionais e permitiu a milhões de homens e mulheres viver de maneira mais digna”. Em sua análise teológica denuncia como "contrária ao desígnio de Deus [...] qualquer forma de discriminação quanto aos direitos fundamentais da pessoa" evocando o Concílio Vaticano II (GS 1 e 29), desejando assim que aumente "a fraternidade e a concórdia" entre os povos. Também é o primeiro pontífice a tecer uma 
crítica à DUDH pela ausência de uma "base antropológica e referências morais explicitas", contudo, não nega que seus princípios devem ser "enraizados nas tradições, culturas e religiões", provendo uma pluralidade no exercício das liberdades proclamadas no documento.

Ao apontar para os principais desafios de aplicação da DUDH, observa que muitos dos direitos fundamentais proclamados, codificados e celebrados "ainda são objeto de violações graves e contínuas" e alude aos novos "atores internacionais, pessoas ou organizações" (organismos regionais, terceiro setor, organismos financeiros), além do Estado", que também devem ser submetidos à regulamentação da DUDH, como detentores do destino da população. Sobre as principais violações denunciadas faz uma análise quanto à escolha de um certo direito em detrimento dos demais, com base em interesses particulares, enfatizando ainda a "confusão de liberdade com permissividade, ou para se assegurarem vantagens que têm a solidariedade humana em pouco apreço". Desta forma, retoma a universalidade e equidade dos direitos humanos ao afirmar que o individualismo e o domínio dos mais fortes "atenuam o vínculo solidamente estabelecido pelo texto, entre liberdade e justiça social”. Com isso, faz um apelo para que a Declaração seja vivida e observada como um todo. Entre seus destaques, desafia as nações ao acolhimento, quando da "liberdade humana e a solidariedade entre as pessoas e as culturas" que "se encontram e se fecundam reciprocamente", em referência à universalidade dos direitos humanos, que, se contestada, pode ameaçar o todo dos direitos do homem. Faz um comentário sobre a necessidade da prática da solidariedade e da fraternidade e, assim, da realização plena dos direitos estabelecidos pela Declaração, quanto à existência de diferentes realidades no mundo, coexistindo muitos irmãos e irmãs "afligidos pelas calamidades naturais, dizimados pelas doenças, prostrados na ignorância e na pobreza ou vítimas de guerras cruéis e intermináveis" ao lado de outras pessoas que se destacam pela pela ostentação e atenção ao supérfluo. O ensinamento da "história conturbada destes últimos cinquenta anos" é que "a dignidade, a liberdade e a felicidade jamais serão completas sem a solidariedade" (JOÃO PAULO II, 1998a). 
Um pouco antes da celebração dos 50 anos, em 04 de julho de 1998, João Paulo II propôs que houvesse a criação da Pastoral dos Direitos Humanos (AURENCHE, 2007, p. 302-303), que deveria ter dois objetivos, o 1) "fazer com que a aceitação dos direitos universais na 'letra' leve à prática concreta do seu 'espírito"', como já havia apontado em sua Encíclica Redemptor hominis (n. 17); 2) apresentar "as questões essenciais relativas à situação do homem hoje e no futuro [...] com objetividade, lealdade e sentido das responsabilidades", e aqui destaca as condições econômicas e sociais que resultam na contradição de coexistência entre "pobreza extrema" de muitos e "opulência" de outros (JOÃO PAULO II, 1998b, n. 1-2):

Com muita frequência, as pessoas mais pobres, por causa da precariedade da sua situação, tornam-se as vítimas atingidas de modo mais sério pelas crises económicas, que afetam os países em vias de desenvolvimento. A prosperidade económica, deve-se recordar, é antes de tudo o fruto do trabalho humano, dum trabalho honesto e muitas vezes penoso. A nova arquitetura da economia em escala mundial deve basear-se sobre os fundamentos da dignidade e dos direitos da pessoa, sobretudo o direito ao trabalho e à proteção do trabalhador (JOÃO PAULO II, 1998b, n. 4).

Enfatiza a tarefa da Pastoral dos Direitos Humanos de usar a dimensão educativa nas comunidades cristãs e na sociedade com importância particular, pois só a "educação para o respeito dos direitos humanos levará naturalmente à criação duma verdadeira cultura dos direitos humanos, necessária para que funcione o estado de direito e para que a sociedade seja realmente fundada sobre o respeito pelo direito" (JOÃO PAULO II, 1998b, n. 5).

\section{Mensagem Pontifícia de Bento XVI pelo aniversário da DUDH}

Bento XVI (2005-2013) foi o pontífice que menos escreveu sobre os Direitos Humanos e seu discurso sobre a DUDH é o mais sintético. Em 10 de dezembro de 2008, faz seu primeiro Discurso na ocasião do $60^{\circ}$ Aniversário da Declaração Universal dos Direitos Humanos. Em sua 
análise histórica faz referência à universalidade dos direitos fundamentais, a despeito de como possa ser compreendida por diferentes culturas, atuando como um "guia universal e um denominador comum entre os diferentes" (BENTO XVI, 2008).

Entretanto, em sua análise teológica evoca a razão de ser dos "direitos fundamentais" que, "além das diferentes formulações e do diverso peso que podem revestir no âmbito das várias culturas”, são universais porque inscritos na própria natureza do homem, a saber a "lei natural, escrita por Deus na consciência humana”. Deste modo, os Direitos Humanos estão "fundados em Deus criador, o qual concedeu a cada um a inteligência e a liberdade", de modo que, se esta "sólida base ética" for prescindida, os "direitos humanos permanecem frágeis porque privados de fundamento sólido", estabelecendo assim uma relação entre a suposta fragilidade dos fundamentos da DUDH e a descristianização, ou ainda, a secularização do mundo contemporâneo (BENTO XVI, 2008).

Entre as principais violações denunciadas pelo papa alemão, reside o fato de que "centenas de milhões de nossos irmãos e irmãs ainda vêem ameaçados os seus direitos à vida, à liberdade, à segurança" e "novas barreiras são levantadas por motivos relacionados com a raça, a religião, as opiniões políticas ou outras convicções", como já apontara João Paulo II em 1988. Apesar de pouco contribuir com alguma novidade, mas repetir, de modo geral, alguns aspectos da leitura wojtyliana da DUDH, se destaca a novidade que é a "referência do diálogo intercultural sobre a liberdade e sobre os direitos do homem". Tal interculturalidade pode ser entendida como exercício de "respeito", "diálogo" e "solidariedade" (BENTO XVI, 2008).

\section{Mensagem Pontifícia de Francisco pelo aniversário da DUDH}

Em 10 de dezembro de 2018, o Papa Francisco (2013-) escreve sua primeira Mensagem na ocasião do $70^{\circ}$ Aniversário da Declaração Universal dos Direitos Humanos aos Participantes na Conferência Internacional “Os Direitos Humanos no Mundo Contemporâneo: Conquistas, Omissões, Negações", promovida pelo Dicastério para o Serviço do Desenvolvimento 
Humano Integral e pela Pontifícia Universidade Gregoriana, nos dias 10 e 11 de dezembro de 2018. Na análise histórica de Francisco, faz referência aos instrumentos jurídicos internacionais, a Declaração e o Programa de Ação de Viena (1993), que reconhecem a igual dignidade de todos radicados na natureza humana que constitui a "família das Nações" e "da qual derivam direitos e liberdades fundamentais" que são "universais, indivisíveis, interdependentes e interligados". Também reconhecem que cada indivíduo "tem deveres em relação à comunidade, na qual unicamente é possível o livre e pleno desenvolvimento da sua personalidade". A análise faz ainda alusão aos atores internacionais historicamente responsáveis pela defesa, promoção e garantia dos Direitos Humanos, a saber: representantes dos Estados junto da Santa Sé, das instituições das Nações Unidas, do Conselho da Europa, das Comissões episcopais Justiça e Paz e daquelas para a pastoral social, do mundo acadêmico e das organizações da sociedade civil, colocando a igreja em igual responsabilidade com todas as esferas, nacionais, regionais e locais (FRANCISCO, 2018).

Sua análise teológica incide sobre as raízes evangélicas dos Direitos Humanos, especialmente daqueles que são "invisíveis": "de muitos que têm fome e sede, que estão nus, doentes, são estrangeiros ou presos (cf. Mt $25,35-36$ ), que vivem à margem da sociedade ou são por ela descartados". Os Direitos Humanos para Francisco emanam da "exigência de justiça e de solidariedade" cara aos cristãos que são interpelados pelo Evangelho "a dirigir o olhar para os mais pequeninos dos nossos irmãos e irmãs, a sentir compaixão (cf. Mt 14, 14) e a comprometer-nos concretamente para aliviar os seus sofrimentos" (FRANCISCO, 2018).

Entre os principais desafios elencados pelo papa argentino tem especial atenção "pôr os direitos humanos no centro de todas as políticas, inclusive as de cooperação ao desenvolvimento, mesmo quando isto significar ir contracorrente". Deste modo chama todos a agirem pelas causas dos Direitos Humanos, especialmente aos que são invisíveis, devendo ter um comprometimento com ações concretas. As principais violações denunciadas por Francisco residem no fato de que "persistem hoje no mundo inúmeras formas de injustiça, alimentadas por visões antropológicas redutivas e por um modelo econômico fundado no lucro, que não hesita em explorar, descartar e até matar o homem”. Menciona 
diferentes direitos em constante violações, abortos, acesso a bens materiais para uma vida digna, sem acesso à educação, desempregados, trabalhadores escravos, presos em situação degradante, torturados e sem acesso à justiça e vítimas de desaparecimentos forçados. Faz uma referência específica à violação dos direitos de pessoas que "vivem num clima dominado pela suspeita e pelo desprezo", dos que vivem na intolerância, discriminação e violência por causa racial, étnica, nacional ou religiosa. Também se refere às violações por conflitos armados, "enquanto mercadores de morte sem escrúpulos se enriquecem com o preço do sangue dos seus irmãos e irmãs". Pode ser identificada entre seus destaques a prioridade a ser dada aos mais vulneráveis, fruto das contradições do sistema econômico que permite ter "uma parte da humanidade [que] vive na opulência", enquanto "outra parte vê a própria dignidade não reconhecida, desprezada ou espezinhada e os seus direitos fundamentais ignorados ou violados" (FRANCISCO, 2018).

\section{Conclusão}

Há inegavelmente uma mudança de mentalidade na Igreja Católica a respeito da Declaração Universal dos Direitos Humanos, desde o receio a uma progressiva incorporação da sua gramática. Entretanto, para a Igreja pós-conciliar a partir de 1965, a DUDH é um elemento indispensável e lido a partir de uma hermenêutica teológica conciliar. A permanência dos Direitos Humanos em todos os pontificados pós-conciliares é uma das grandes marcas do catolicismo contemporâneo e um dos grandes frutos do Concílio Vaticano II. João XXIII é o primeiro papa a incorporar a gramática dos Direitos Humanos nos documentos oficiais do Magistério da Igreja Católica. Em sua perspectiva há correlação indissociável entre a garantia da liberdade humana e a responsabilidade com a justiça social, duas grandes ênfases hermenêuticas conciliares. Tais aspectos irão se prolongar na teologia conciliar, presentes acentuadamente e respectivamente na Declaração Dignitatis Humanae e na Constituição Pastoral Gaudium et Spes. Os pontificados pós-conciliares irão aprofundar cada uma dessas perspectivas de acordo com a hermenêutica magisterial 
que cada papa irá fazer dos acontecimentos históricos de seu contexto, presentes na leitura dos desafios que apontam e violações que denunciam.

Do ponto de vista da pertinência da DUDH e das dificuldades de sua realização, Paulo VI reconhece a potencialidade da Declaração enquanto instrumento jurídico, mas também como potencial ferramenta política na busca pela dignidade humana. João Paulo II faz referência constante às liberdades, especialmente à liberdade religiosa, tendo os direitos civis como ponto de destaque. Reconhece a DUDH como instrumento jurídico, assim como as comissões ad hoc e na expectativa de resultados, incluindo nas legislações nacionais os preceitos do documento. Bento XVI é o primeiro a falar sobre interculturalidade, mas coloca os Direitos Humanos em uma categoria de direito natural, que dificulta o diálogo. Francisco faz um apelo social em que reconhece os diferentes grupos, instituições e indivíduos, não só os Estados, como atores na realização dos DH e também chama à cooperação entre eles, com a dignidade humana prevalecendo dentre interesses. Quanto às ênfases teológicas da DUDH, Paulo VI continua a dinâmica de avançar as mudanças prenunciadas pelo Concílio e entende que todo tipo de discriminação dos direitos humanos é "contrário ao desígnio de Deus". Ademais, as raízes dos Direitos Humanos residem na fraternidade, justiça e igualdade do próprio evangelho, em sua regra de ouro (Mt 7,12).

João Paulo II também correlaciona os Direitos Humanos ao Evangelho, mas em sua primeira mensagem enfatiza de modo mais acentuado a dimensão da liberdade religiosa. A ênfase à liberdade religiosa é resultado de seu combate ao comunismo e à perseguição religiosa promovida pelo regime. Entretanto, a persistência na valorização da liberdade religiosa chega a incorrer no risco de uma visão romântica da religião, como se ela fosse sempre colaborativa com a defesa, promoção e garantia dos Direitos Humanos, e a sua relação com Deus sempre trouxesse uma contribuição a mais na sociedade, sem levar em conta todos os escândalos de pedofilia que surgem em seu pontificado como atentado direto contra os Direitos Humanos. Entretanto, reafirma veementemente que a defesa dos Direitos Humanos é própria da missão da Igreja. Também se verifica sua influência kantiana de centralizar a importância e os resultados da declaração oriundos do meio jurídico, em que a inserção na 
Constituição seria suficiente para as mudanças da sociedade. O sul global, por exemplo, fica muito aquém de ser efetivamente atendido por suas representações constitucionais. Em suas duas outras mensagens, insere, por um lado, o debate sobre os "fundamentos transcendentes dos direitos humanos" e aponta como uma das causas da insuficiência da DUDH a ausência de uma "base antropológica e referências morais explícitas", apostando em seu personalismo filosófico de chamar as pessoas a viverem sua vocação cristã como vocação à promoção dos Direitos Humanos. Por outro lado, passados 9 anos da queda do muro de Berlim, e tendo em vista o livre curso do capitalismo, denuncia como contrária à vontade de Deus a desigualdade escandalosa dos países em desenvolvimento, alertando para a condição das pessoas mais pobres e para a necessidade de proteger o trabalhador, engrenagem pela qual se criam fortunas alheias. Bento XVI, por sua vez, continua com alguns aspectos de João Paulo II, dando ênfase à questão da liberdade, em especial a liberdade religiosa, e sugere resolver o problema da fragilidade antropológica com a controversa questão da lei natural e a necessidade de voltar a Deus, para consolidação dos Direitos Humanos, reforçando a visão wojtyliana mais essencialista e, portanto, potencialmente mais romântica da religião, sem dar a devida consideração ao momento em que começam os atentados terroristas com motivações religiosas. Entretanto, insere o elemento de diálogo intercultural como forma de alcançar uma cultura de solidariedade.

Francisco, por sua vez, retoma a hermenêutica da justiça social partindo dos mais vulneráveis, como caminho de crescimento da própria liberdade, ao assumir sua responsabilidade com a comunidade. E a fundamentação disso nada mais é que a exigência de justiça e solidariedade, sobretudo aos que mais precisam, como dimensão cara aos cristãos e responsabilidade social de todos os atores envolvidos em prover dignidade a todos seres humanos. Nessa hermenêutica da justiça social, os Direitos Humanos constituem como que a dimensão antropológica do Evangelho, na qual a justiça é que confere o verdadeiro valor quer da religião, quer das instituições. Parece assim evocar o caminho primeiro do Concílio de que a constituição de "única família humana" (GS 29,3) passa pelo estabelecimento de uma "vida política verdadeiramente humana" e exige a tarefa de "fomentar sentimentos interiores de justiça e benevolência e 
serviço do bem comum" (GS 73,5). Os Direitos Humanos em Francisco são a expressão concreta da fraternidade universal apregoada pelo Evangelho.

\section{Bibliografia}

AURENCHE, G. Églises engagées pour les Droits de L'Homme : défis et exigences. In : AGI, M. (dir.). Christianisme et droits de l'Homme. Paris : Des Idées et des Hommes, 2007. p. 289-306.

BENTO XVI. Discurso na Comemoração do Sexagésimo Aniversário da Declaração Universal dos Direitos do Homem, de 10 de dezembro de 2008. Vaticano: Libreria Editrice Vaticana, 2008.

BOBBIO, N. A Era dos Direitos. Trad. Carlos Nelson Coutinho. Rio de Janeiro: Editora Elsevier, 2004.

CALDEIRA, R. C. Considerações sobre a Igreja Católica Romana e a evolução de sua compreensão sobre os direitos humanos. Horizonte, Belo Horizonte, v. 15, n. 47, p. 770-796, 2017.

FRANCISCO. Mensagem aos Participantes na Conferência Internacional "Os Direitos Humanos no Mundo Contemporâneo: Conquistas, Omissões, Negações”. 10-11 de dezembro de 2018. Vaticano: Libreria Editrice Vaticana, 2018.

GONÇALVES, P. S. L. Verbete Paulo VI. In: PASSOS, J. D.; SANCHEZ, W. L. (Coord.). Dicionário do Concílio Vaticano II. São Paulo: Paulinas/Paulus, 2015. p. 720-731.

JOÃO PAULO II. Mensagem ao Secretário-Geral das Nações Unidas, por ocasião do 30 Aniversário da Declaração dos Direitos Humanos. 2 de dezembro de 1978. Vaticano: Libreria Editrice Vaticana, 1978.

JOÃO PAULO II [JUAN PABLO II]. Mensaje con motivo del 40 Aniversario de la Declaración Universal de los Derechos del Hombre. 6 de diciembre, 1988. Vaticano: Libreria Editrice Vaticana, 1988. 
JOÃO PAULO II. Mensagem por ocasião do $50^{\circ}$ Aniversário da Declaração Universal dos Direitos do Homem. 30 de novembro de 1998. Vaticano: Libreria Editrice Vaticana, 1998a.

JOÃO PAULO II. Discurso aos Participantes no Congresso Mundial sobre a Pastoral dos Direitos Humanos. 4 de julho de 1998. Vaticano: Libreria Editrice Vaticana, 1998b.

JOÃO XXIII. Carta Encíclica Mater et Magistra. 9. ed. São Paulo: Paulinas, 1991.

JOÃO XXIII. Carta Encíclica Pacem in Terris. 3. ed. São Paulo: Paulinas, 1995.

KLOPPENBURG, B. Notas. In: CONCÍLIO VATICANO II. Compêndio do Vaticano II. Petrópolis: Vozes, 2000.

ORGANIZAÇÃO DAS NAÇÕES UNIDAS (ONU). Declaração Universal dos Direitos Humanos. 2017 (III) A. Paris, 1948. Disponível em: <http://www.un.org/en/universal-declaration-human-rights/>. Acesso em: 11 fev. 2019.

PAULO VI [PAOLO VI]. Radiomessaggio Natalizio al Mondo. 23 dicembre 1965. Vaticano: Libreria Editrice Vaticana, 1965.

PAULO VI [PAOLO VI]. Lettera Apostolica (Motu Proprio) Ecclesiae Sanctae. 6 agostos 1966. Vengono promulgate norme per l'applicazione di alcuni Decreti del Concilio Vaticano II. Vaticano: Libreria Editrice Vaticana, 1966.

PAULO VI. Carta Encíclica Populorum Progressio sobre o Desenvolvimento dos Povos. 26 de março de 1967. Vaticano: Libreria Editrice Vaticana, 1967a.

PAULO VI [PAOLO VI]. Lettera Apostolica (Motu Proprio) Catholicam Christi Ecclesiam. Vengono istituiti il «Consiglio dei Laici» e la Pontificia Commissione di studio «Giustizia e Pace». 6 gennaio 1967. Vaticano: Libreria Editrice Vaticana, 1967b.

PAULO VI [PABLO VI]. Mensaje a la Conferencia de Teherán con motivo del 20 aniversario de la Declaración de los Derechos Humanos. 15 de abril de 1968. Vaticano: Libreria Editrice Vaticana, 1968.

PAULO VI [PABLO VI]. Mensaje en el XXV Aniversario de la Declaración Universal de los Derechos Humanos. 10 de diciembre de 1973. Vaticano: Libreria Editrice Vaticana, 1973. 
VILLAS BOAS, A.; VILLAS BOAS, A. V.

QUEIROZ, J. J. Verbete Direitos Humanos. In: PASSOS, J. D.; SANCHEZ, W. L. (Coord.). Dicionário do Concílio Vaticano II. São Paulo: Paulinas/Paulus, 2015. p. 288-292.

VILLAS BOAS, A. Verbete Verdade. In: PASSOS, J. D.; SANCHEZ, W. L. (Coord.). Dicionário do Concílio Vaticano II. São Paulo: Paulinas/Paulus, 2015. p. 1003-1006.

Recebido: 11/02/2019

Received: 02/11/2019

Aprovado: 12/04/2019

Approved: 04/12/2019 